\title{
Shantytowns, Housing and State Order: The Plan de Emergencia in 1950s Argentina
}

Dr. Adriana Laura Massidda

Leicester School of Architecture, De Montfort University

adriana.massidda@dmu.ac.uk

This is the original manuscript of an article accepted for publication in Planning Perspectives, Taylor \& Francis. The manuscript was accepted in March 2020 and is currently under production.

Please do not circulate and refer to the latest version for citations. 


\section{Introduction}

This article examines a specific juncture in the urban history of Buenos Aires, the mid1950s, to argue that it constituted a key moment when earlier ideas regarding housing and planning were revisited, preparing the way for the policies which would follow in later decades, and simultaneously reflecting contemporaneous local and international concerns. More specifically, the article will analyze the way in which Argentine shantytowns were first conceived of by the state, the contradictions and tensions this conception presented within a housing policy context which was changing dramatically, and the close engagement of these discussions with the inter-American planning debate. To this aim the article takes a key state document of the period, the Plan de Emergencia (Emergency Plan; PE; 1956), as a case study, since it represented not only the first shantytown eradication plan in Argentina but also a document which intended to change the course of housing policy in the country. ${ }^{1}$ The PE was a vivid reflection of the national political context. First, it aligned with the economic line adopted by the national government, which included the deregulation of the market and a gradual retraction of the bargaining and social rights gained by workers over the previous decade. The recommendations of the PE applied such policies to housing development and the construction industry. Second, it followed recommendations for Latin-American governments promoted in inter-American meetings in a context where the Argentine ruling classes were moving closer to the United States and its Cold War designs. Not least, the PE condensed judgements about the shantytowns that were widely spread in the mid-twentieth century, such as those which held the residents responsible for their own housing situation. In this way it condensed a large number of debates and perspectives of

\footnotetext{
${ }^{1}$ Comisión Nacional de la Vivienda, Plan de Emergencia.
} 
its time and was also to be influential in later decades.

In a synchronic perspective (this is, cutting through the state of the arts of a given problem in a given moment in time), ${ }^{2}$ the PE stands as an excellent source for analysing the complexity of interrelated discussions on housing, shantytowns, migrations, and the role of the state and the market in 1950s Argentina. On the one hand, the members of the commission which wrote the PE were appointed representatives of ministries, associations and public institutions, which meant that its composition distinctly reflected the heterogeneity of the governing political coalition. In this sense, the article underlines the tight relationship between the PE and the national political agenda. Simultaneously, however, the commission included key professional figures of the time and therefore its discussions also condense the main contemporaneous perspectives toward shantytowns, planning and housing. Furthermore, in a Cold War context where planning debates were rapidly gaining momentum, ${ }^{3}$ the $\mathrm{PE}$ writing commission sought to engage with them by picking up on the housing ideas debated at the most recent Inter American conference (Caracas, 1954) and by sending a delegate to the First Inter-American Technical Meeting on Housing and Planning (Bogotá, 1956), where the Inter-American Planning Society would be created. In this way the PE, as a state and technical document, sheds light on key social, political, urban and economic aspects of its historical context.

In a diachronic perspective (attending to the evolution and changes in the ideas involved), meanwhile, this article argues that the PE picked up a long-standing debate, that on slum clearance, and applied it to the contemporaneous phenomenon of shantytowns. The years 1955-1958 have been traditionally considered a transitional

\footnotetext{
${ }^{2}$ Ferdinand de Saussure's Course in General Linguistics, 79-181.

${ }^{3}$ Benmergui, "Housing Development”; Gorelik, "Pan American Routes".
} 
moment in Argentine history and for such reason very often disregarded, or studied as part of longer time spans. This article, on the contrary, is interested in this specific period precisely for the transitional character that it implies. Produced within this context, the PE was the first in a series of national and municipal attempts at evicting shantytowns in Argentina. Thus, while recasting aspects of the housing discussion that had been advanced earlier in the century, it set up a founding precedent for later initiatives.

This article offers a unique contribution to housing and shantytown history in Buenos Aires. Despite its key role for housing policy history, the PE has received scarce focused scholarly attention, and when studied it has been usually addressed as part of broader developments. ${ }^{4}$ Regarding shantytowns, the growing interest on urban informality in Argentina (and globally) has not yet translated into systematic scholarship about their histories. ${ }^{5}$ Their earlier decades of expansion, in particular, remain notably unrevised, although some works which address this gap are starting to emerge. ${ }^{6}$ More generally, despite raising enthusiasm about the cultural history of 1960s Buenos Aires, ${ }^{7}$ the urban plans implemented between 1955 and 1976 have been seldom analyzed, as have the state initiatives toward shantytowns. ${ }^{8}$ Finally, the works of Leandro Benmergui and Adrián Gorelik have pioneed academic discussion on inter-American professional networks and their relation to the Argentine intelligentsia regarding housing and planning

4 Yujnovsky, Claves políticas; Liernur, "Las políticas de vivienda de la 'Revolución Libertadora'..."; Massidda, "The Plan de Emergencia (1956)", Scroope: The Cambridge Architecture Journal, 21 (2012), 42-51; González Duarte, Villas miseria.

${ }^{5}$ Cravino, Los mil barrios informales; Fischer, McCann and Auyero (eds.), Cities from Scratch; McFarlane and Waibel (eds)., Urban Informalities.

${ }^{6}$ Snitcofsky, "Villas de Buenos Aires"; Camelli, "Politicidad villera"; Massidda, "Utopian Visions for Buenos Aires Shantytowns".

${ }^{7}$ Manzano, The Age of Youth in Argentina; Sánchez Trolliet, “'Buenos Aires Beat””.

${ }^{8}$ Benmergui, "The Alliance for Progress ..." Massidda, "Design Exchanges...". 
over the second half of the twentieth century, but they represent only the start of a much larger and crucial enterprise. ${ }^{9}$ The present article therefore contributes to the existing literature by deepening the existing analyses on the first shantytown eradication plan in Argentina, leading to a more thorough understanding of the origins of the current problems under analysis.

\section{Local Anxieties: Post-Peronism and the Expansion of Shantytowns}

In September 1955 in Argentina a coup d'état backed by a heterogeneous coalition of military and civil actors overthrew the elected government of Juan Domingo Perón. After almost a decade of social and economic changes which included the levelling up of real wages, expanded welfare, and government intervention in economic matters, Peronism had inspired both fervent support and strong opposition. The dictatorship which ensued, self-styled Revolución Libertadora (Liberating Revolution; RL), came to power with a vehement anti-Peronist discourse but with no concrete economic or political plan. ${ }^{10}$ In fact, even though its measures tended, very broadly, to liberalise the economy, the RL supporters' diversity of interests and positions prevented it from setting out a clear government agenda beyond the rejection of Peronism:

\footnotetext{
${ }^{9}$ Gorelik, "Pan American Routes".

10 James, Resistance and Integration; De Riz and Torre, "Argentina since 1946"; Torrado, Estructura social de la Argentina; Sáenz Quesada, La Libertadora.
} 
The country's Navy, Air Force and Army again leave their barracks and quarters to intervene in the Nation's civic life. We do this driven by the imperatives of the love for Freedom, and for the honour of a subjugated people [...]. ${ }^{11}$

Perón had been democratically elected in 1945, and again later in 1952, with extensive support from the working classes. His administration had enhanced workers' rights and provided them with social benefits; had promoted light national industry; and had restricted international investment and free trade, also strongly taxing agriculture. State intervention helped the government to control export prices, thus raising real wages, and to support national manufacturing. The centralization of decisions and administration in the state, furthermore, ensured expanded public employment. Thus, Perón's supporters extended beyond the working classes, including, to some degree, the middle classes, most industralists, and the Nationalist wings of the Armed Forces. Perón rejected foreign political influence, and discouraged engagement with inter-American organizations. ${ }^{12}$

Regarding access to accommodation the Peronist government introduced the concept of right to housing, which asserted people's right to live in appropriate homes and state responsibility for its provision. This differed not only from liberal conceptions where individuals were deemed the main responsible ones for their wellbeing, but also from conceptions where housing the poor was seen as a charitative or humanitarian act. Indeed previous discussions had paved the way for this approach, increasingly underlining the need of further state intervention in social matters. Peronism however considered housing one of the pillars of its welfare policies and facilitatedaccess to it

\footnotetext{
${ }^{11}$ Eduardo Lonardi's speech when assuming the de facto presidency. Comisión de Afirmación de la Revolución Libertadora, A 30 años de la Revolución Libertadora, 175. All translations are by the author unless otherwise indicated.

${ }^{12}$ Potash, The Army and Politics..., 04-14.
} 
through direct action (social housing funded directly by the state and sold to the inhabitants in instalments) and indirect action (affordable mortgages). The concept of right to housing left an indelible mark in people's memories and largely outlived Peronism. $^{13}$

The deepening of industrialisation and expansion of the services sector had increased migration to larger cities and with it the few accretions of shacks that existed before the 1940s had expanded, while new ones had emerged, leading to a growing presence of shantytowns in the urban landscape. In fact, overcrowding grew more rapidly than what Perón's housing and mortgage programmes could cope with. Given the abundance of employment and housing opportunities, shantytown residents expected to be soon able to move out. However, after 1955, the fall in real wages combined with the gradual retreat of the state from social housing and accessible mortgages resulted in a scenario where the permanence of shantytowns became increasingly evident (Fig. 1). ${ }^{14}$

Peronism had attracted the opposition of land owners and businessmen for its high taxation of agricultural exports, destined to subsidy the development of national industry, and of some employers due to the strengthening of workers' bargaining rights. In addition, Peronism arouse criticism from the Left for not challenging the basis of the productive structure. Perón's limited tolerance to active political opposition only widened this gap. Moreover, in the context of the post-war, many members of the middle class interpreted Peronism as an Argentine version of European fascism, which they rejected. Last but not least, some resented the symbolic social prominence gained by the working classes. Such an heterogeneous set of concerns meant that, after an initial moment of

\footnotetext{
${ }^{13}$ Ballent, Las huellas de la politica, pp.31-32; Aboy, "'The Right to a Home"”.

${ }^{14}$ Snitcofsky, "Villas de Buenos Aires"; Germani, "El proceso de urbanización en la Argentina"; Auyero, Poor People's Politics, 50-57; Liernur, "De las 'nuevas tolderías'...”.
} 
support for the RL, it became evident that the differences amongst its supporters hindered the government's capacity to put together an overarching programme for the country. Indeed, the 1955 coup d'état was supported by a wide spectrum of military and civil actors that ranged from conservatives and liberals to socialists and members of the centrist Unión Cívica Radical (Radical Civic Union, UCR), including land owners, businessmen and middle-class professionals. These groups had gathered together to overthrow Perón's government, but their internal contradictions soon became apparent. The leader of the coup d'état, Eduardo Lonardi, of Nationalist ideas, stood in power for a few months, but was quickly replaced by a raising military figure, Pedro Eugenio Aramburu, with a liberal economic approach. After two years marked by internal tensions, the RL called for elections in which Peronism was not allowed to compete. The military government handed over the presidency to the elected candidate, Arturo Frondizi, in 1958, nevertheless keeping a high degree of control over his administration. ${ }^{15}$

Despite the striking differences amongst the RL supporters, some prevailing policies can be outlined. In the economic field the RL sought to gradually deregulate the economy and to open the country to foreign investment, also restricting workers' social benefits and bargaining rights. Related to this, in the political arena, trade unions were intervened and Peronism - largely the political sympathy of unionised workers proscribed. ${ }^{16}$ Internationally, in the context of the Cold War, the RL sougth to align with the United States, abandoning Perón's notions of self-determination. Not least, in the social field, the protagonism and freedom that the working classes had enjoyed during Peronism was severely undermined.

15 James, Resistance and Integration; de Riz and Torre, "Argentina since 1946", 73-101; Podalsky, Specular City, 3-7; Ballent, Las huellas de la política, 38-39.

${ }^{16}$ De Riz and Torre, “Argentina since 1946”, 96. 
In addition, the urban relevance gained by the shantytowns during Peronism greatly disturbed the groups that supported the RL. First, for extreme anti-Peronists, the villas miseria - the Argentine name for local shantytowns - were a result of Perón's demagogery and the proof of his policies failure. As such, they were contingent and reversible once the policies had changed. Furthermore, in the context of modernization theory, shantytowns were generally regarded as a vestige of a rural past which had no place in modern society. ${ }^{17}$ Simultaneously, Catholic groups were particularly alarmed by the overcrowding conditions in which families lived. Finally, for the Left, the shantytowns were the disturbing counter-face of a society that failed to extend the benefits of economic growth to all its members. Thus, the RL plan of eradicating the shantytowns by re-accommodating its residents into purpose-built complexes of social housing had the potential of addressing all these concerns in a single move.

\section{The Comisión Nacional de la Vivienda and its approach}

Within the described context one of the few aspects on which the RL supporters coincided was on the need of clearing out problems left, in their views, by the previous administration. Convinced that these should be approached through technical bodies, the government appointed several temporary commissions to address specific issues, creating the Comisión Nacional de la Vivienda (National Housing Commission; CNV) to deal with housing. ${ }^{18}$ The CNV members were representatives of ministries, state banks, unions and industrial associations related to construction, reflecting the heterogeneous coalition

${ }^{17}$ Benmergui, "The Transnationalization of the 'Housing Problem",; Gorelik, "Pan American Routes".

${ }^{18}$ Decree 6.404; Comisión Nacional de la Vivienda, Plan de Emergencia, 14. 
that supported the RL. Not only did the members of the CNV come from diverse political backgrounds, but in many cases they had slightly different positions about housing as well. The CNV president, for example, Luis Vicente Migone, was a civil engineer active in designing built-to-rent apartments for the higher and middle classes during the 1940s. ${ }^{19}$ During those decades Migone had promoted prefabrication and improvements for the construction industry, and in 1944 he had taken part in the writing of the 1944 Buenos Aires building regulations after a study of United States planning codes ${ }^{20}$ Following this interest he had taken part in the writing of the 1944 Buenos Aires building regulations, which are, with amendments, in force until today. Migone had also been president of the Centro Argentino de Ingenieros (Argentine Engineers Centre, CAI) and co-founder of the Cámara Argentina de la Construcción (Argentine Construction Chamber, CAC).

In 1939 Migone attended the First Pan-American Congress of Low-Cost Housing (Buenos Aires) as representative of the CAI, and from 1943 to 1946 he was a member of a housing commission previous to the $\mathrm{CNV}$, the Comisión Asesora de la Vivienda Popular (Advisory Commission of Popular Housing). Migone was interested in enganging with inter-American networks and in 1947 had contributed to create the Pan American Federation of Engineers. ${ }^{21}$ The appointment of an engineer to the role of president of the CNV is an eloquent statement about the government's technocratic approach. More importantly, the designation of Migone in particular, with his strong

\footnotetext{
${ }^{19}$ Migone, "Casa de renta..."; Migone, "Casa de departamentos reducidos".

${ }^{20}$ Migone, "La vivienda popular y la técnica"; Migone, Las ciudades de los EE.UU.; Lecuona, “Conceptos políticos y sociales...", 37-39.

${ }^{21}$ Liernur, "Las políticas de vivienda...”, 71; Unión Panamericana de Asociaciones de Ingenieros, "Historia".
} 
connections to the $\mathrm{CAI}$ and the $\mathrm{CAC}$, reflects the influence that the construction industry would have on governmental decisions.

Antonio Bonet, general secretary of the $\mathrm{CNV}$, was one of the most notorious architects in Buenos Aires at the time. Other well-known members of the CNV were architects José Aslan, Jorge Kalnay, Bartolomé Repetto and Jaime Roca, as well as civil engineers Antonio Vilar and Benito Carrasco. Like Bonet, many of these had helped disseminating modern architecture. Nicolás Babini, executive secretary, was a young lawyer affiliated to the UCR who had written on low-cost housing. José Pastor, meanwhile, was an architect from a Catholic background who had published profusely about UK and US urban and regional planning concepts such as the garden city, the neighbourhood unit, or the work of the Tennessee Valley Authority, in the local architectural journal Nuestra Arquitectura. In 1950 he had been in charge of formulating a plan for the reconstruction of the city of San Juan, partially destroyed by an earthquake. Walter Hylton Scott was a Socialist engineer, founder and director of Nuestra Arquitectura. Thus, the CNV gathered together key professional figures its times, and its work can be read as a snapshot of the contemporaneous intelligentsia's thought about shantytowns. $^{22}$

The CNV was charged with informing the government about the housing shortage and possible ways to overcome it. Its first report, the PE, was due within two months and expected to advance solutions for the most urgent housing problems. The CNV interpreted the shantytowns to be one of these, and it proposed to clear them relocating its inhabitants into purpose-built social housing neighbourhoods. Furthermore, it outlined

\footnotetext{
${ }^{22}$ Vilar, "La vivienda popular"; Babini, Realidad y destino de la vivienda; Pastor, "La vivienda popular"; Pastor, “Anatomía de la unidad vecinal”; Healey, The Ruins of the New Argentina, 199-200 and 250-4; Hylton Scott, "La vivienda popular".
} 
a series of recommendations to lower housing construction costs and to encourage the private investment. The CNV was in addition charged to produce a second report, Plan Integral (Integral Plan, PI), to outline longer-term housing and planning strategies for the future growth of the city. ${ }^{23}$ Like the RL, the CNV employed quite a loaded rhetoric, while the heterogeneity of its proposals belied the unresolved contending visions that coexisted within it:

The country emerges prostrated from a tremendous experience [they refer to Peronism]; it must, still convalescent, take its first steps in the path of health - health of body and spirit. This emergency plan is one of those first steps towards the recovery of national plenitude. ${ }^{24}$

A first reading of the PE creates a puzzling impression. First, its two main recommendations, state-sponsored shantytown eradication and the promotion of the private sector, can be seen as mutually contradictory. In fact, the relocation of shantytown residents into state-built accommodation, as outlined in the first half of the PE, would require significant funding to be thoroughly implemented. This stood uneasily with the idea that the state should stop funding housing construction and retain only its regulatory functions, leaving the private sector in charge of housing development, as he second half contended. The CNV introduced some discoursive qualifiers to minimise this clash, but the conflict of visions was itself rooted in the tensions of the political context, and remained unresolved within the document. Second, for what regards the shantytown eradication programme, the $\mathrm{PE}$ jumped straight from a description of the existing settlements to a detailed explanation of the proposal. Being the first programme of its

\footnotetext{
${ }^{23}$ Comisión Nacional de la Vivienda, Informe de la Comisión...; Massidda, "Urban Planning and Undertakings...".

${ }^{24}$ Comisión Nacional de la Vivienda, Plan de Emergencia, 31
} 
kind in Argentina, however, one would have expected a justification of the reasons to take this approach, an evaluation of other alternatives, or at least a gradual introduction of the readers to eradication as a concept. The acceptance of the idea of state intervention into shantytowns by way of eradication is, instead, assumed as shared knowledge with the readers. Examining the engagement of $\mathrm{CNV}$ members with previous and contemporaneous inter-American housing and planning discussions, however, offers important clues: in this sense it is possible to read such discussions as the missing explanation in the PE. Thus, the main ambiguities of the document can be explained by inserting it and reading it within its historical context, national in relation to the first and international in relation to the second.

\section{Global Designs: The Cold War and the Inter-American Debate on Planning and Housing}

The United States had sought to assume a position of leadership within the Americas since its independence, and this endeavour became even more pronounced during the Cold War. In fact, and especially after the Cuban Revolution, the US wanted to ensure Latin-American support for its anti-communist project. ${ }^{25}$ With such aims it went to the $\mathrm{X}$ Inter-American Conference at Caracas in 1954. At the same time, Latin-American nations were concerned about their own economic problems, and expected financial help for internal development and/or more favourable terms of trade with the United States. ${ }^{26}$

\footnotetext{
${ }^{25}$ Taffet, Foreign Aid as Foreign Policy; Iber, Neither Peace nor Freedom; Benmergui, "Housing Development".

26 "Memorandum by the Assistant Secretary..."; "Report..."; "The Acting Secretary of State...".
} 
The general tensions in the $\mathrm{X}$ Conference also affected the discussion about housing. As intimated, such discussion was not new. Already in 1939 the First PanAmerican Congress of Low-Cost Housing had been an opportunity not only for the American countries to discuss the housing issues that concerned them, but also for the US to promote itself as leader in the continent's social concerns, displacing European influence from Latin America (Fig. 2). ${ }^{27}$ Several members of the future CNV attended this event, amongst whom Migone himself, Vilar, Carrasco and Julio Silva. The Congress main recommendation, unsurprising in its post-depression context, was for the national states to engage further with social housing provision. The Conclusions also advised to proceed to "the complete elimination of the so called "Îlots insalubres" within the urban radius'. ${ }^{28}$ The term 'Îlots insalubres', used in the Spanish version, was well spread in the contemporary urban discussion, originally refering to inner-city tenements in central Paris. It had been also used in the Athens Charter, a key Modern Architecture document. ${ }^{29}$

After the Second World War, the Inter-American Economic \& Social Council (IA-EcoSoc) of the OAS launched a series of initiatives in the field of housing, amongst which the Inter-American Housing Center (best known for its Spansh acronym, CInVA or Centro Inter-Americano de la Vivienda or) became prominent. For the $\mathrm{X}$ InterAmerican Conference, for example, the IA-EcoSoc appointed an Ad Hoc Committee for the Study of the Problem of Low-Cost Housing to produce a report with analysis and recommendations. The housing discussion at the Conference was mainly centred around this report. ${ }^{30}$ This Report was a foundamental antecedent to the PE, and in fact quoted

\footnotetext{
${ }^{27}$ Ministerio de Relaciones Exteriores y Culto. Primer Congreso Panamericano..., 54-57.

${ }^{28}$ Ministerio de Relaciones Exteriores y Culto. Primer Congreso Panamericano..., 714.

${ }^{29}$ La Charte d'Athènes.

${ }^{30}$ Inter-American Economic and Social Council. Problems of Housing....
} 
directly by the CNV when presenting the key explanations about the emergence of the shantytowns. This one-paragraph long quote is the only quotation from an external source used in the PE. ${ }^{31}$

Just a few months after the launch of the PE, the IA-EcoSoc held the First InterAmerican Technical Meeting on Housing and Planning in Bogotá. A CNV representative attended the event. ${ }^{32}$ The event discussions and conclusions largely followed the Ad Hoc Committee report, and to a certain degree also the 1939 Congress recommendations. For example, they suggested that states provide services to housing already built in plots without infrastructure, which was an idea already introduced in the the Ad Hoc Committee report, which cited the self-help schemes implemented in the 1940s in Puerto Rico. ${ }^{33}$ However, the First Inter-American Technical Meeting conclusions presented it with further strength. Second, the conclusions went back to the idea of slum clearance but this time from a completely refreshed perspective. The Bogotá conclusions did not, in fact, address the issue of degraded housing as a problem of residents' vice, laziness or immorality, as the 1939 Congress or the PE had done. Differently, they stressed the mismatch between people's incomes and standard housing costs. It also included the idea of adaptation houses which, as will be explained below, had one of the key PE proposals; and emphasised the importance of keeping residents within their original area when it referred to slum clearance. ${ }^{34}$

\footnotetext{
${ }^{31}$ Comisión Nacional de la Vivienda, Plan de Emergencia, 43, quoting Inter-American Economic and Social Council, Problems of Housing..., 7.

${ }^{32}$ Comisión Nacional de la Vivienda, Informe de la Comisión..., vol. 1, 22

${ }^{33}$ Inter-American Economic and Social Council, Problems of Housing..., 56.

${ }^{34}$ Inter-American Economic and Social Council, First Inter-American..., 21-27.
} 
The CNV stood as the main Argentine body in charge of building ties with interAmerican planning organisations in a context where the RL actively sought to reposition the country in the international scenario. Indeed, already in 1954 - still under the government of Juan Domingo Perón - and more openly from 1955 onwards, Argentina had sought to improve its relations with the United States, and to engage more thoroughly with the inter-American debate. ${ }^{35}$ The CNV not only engaged actively with the interAmerican housing discussion through the attendance to meeting by its individual members but also by inviting Ernesto Vautier, an Argentine architect who had become a key figure at the CInVA, to visit the country to advise on housing policy amongst similar initiatives. ${ }^{36}$ Beyond the Americas, the $\mathrm{CNV}$ set up delegates' visits and training programmes with the Puerto Rico Planning Board, with the United Nations, and with the International Labour Organisation. ${ }^{37}$

\section{The Plan de Emergencia}

The PE, as intimated earlier, was structured around two coexisting arguments. These entailed different conceptions about the state, the private sector, and the roles of each in the provision of affordable housing; and can be related to the ideas of direct and indirect state action respectively. On the one hand, the $\mathrm{CNV}$ interpreted the eradication of shantytowns as one of the National goverment main tasks, and expected this to be achieved through direct action, i.e., by fully evicting residents and re-accommodating

\footnotetext{
35 “Memorandum of Conversation..."; Sáenz Quesada, La Libertadora, 243-262.

${ }^{36}$ Comisión Nacional de la Vivienda, Informe de la Comisión..., vol. 1, 21-22.

${ }^{37}$ Comisión Nacional de la Vivienda, Plan de Emergencia, 26; Comisión Nacional de la Vivienda, Informe de la Comisión..., vol. 1, 19-29.
} 
them in purpose-built social housing. The PE deemed the residents responsible for their own living conditions, arguing that they lacked working and saving habits and were not concerned about better accommodation, accepting overcrowded conditions instead. They therefore needed to be educated, for example through the inhabitation of the new complexes that the PE proposed.

On the other hand, the PE considered that housing shortage was the consequence of insufficient incentives for the private sector, an excessive centralisation of decisions in the state, and inadequate land management in the face of rural to urban migrations. Following this, it outlined suggestions to foster the construction industry and encourage private initiatives for housing development through indirect action, i.e., through loans, specialized agencies and adjustments to regulation. Ocassionally this referred to affordable housing, but most of the time it referred to housing in general. In this way the Plan implicitly shifted the responsibility for sufficient housing provision to the private sector, assuming that if adequately encouraged it would be able to provide enough supply. While direct action would be typical of interventionist governments, such emphasis on indirect action can be seen as more typical of liberal administrations in the economic sense (Fig. 3).

The coexistence of both perspectives within one single document responded to the persistence of an interventionist conception of the state together with the RL's aim of retreating the state from intervention in the market. Perón's administration had not been the first to consider the state the ultimate responsible for the population's dwelling conditions, but it had been effective in placing this idea solidly in the collective imaginary. In this way, state intervention was conceived of as the way of curbing the housing shortage par excellence - a notion which outlived Peronism. The RL wanted to 
avoid social conflict when imposing economic liberalisation, and for this reason it introduced one without drastically withdrawing the other. ${ }^{38}$

Furthermore, the overlap of approaches in the PE can be also explained by the urgent character assigned to the programme of eradication. In fact, the programme was presented as an unavoidable but one-off action that should be momentarily tolerated due to the urgency of the situation. Presented this way, the high state expenditure it demanded did not necessarily clash with the idea of liberalising the market in broader terms. Indeed, also the elaboration of the PE itself was assigned urgent character, and for this reason the different perspectives within the government's coalition, reflected in the composition of the CNV, had not had time to come to terms with one another. Babini, for example, had expressed some years earlier his disagreement with the idea that private enterprise could provide sufficient affordable housing - a perspective which proved to be key in the PE. ${ }^{39}$

The influence of the inter-American debate can be noted in both arguments. First, for what regards shantytowns eviction and as intimated before, the PE moved from a description of the shantytowns straight to the eradication proposal without justifying the appropriateness of the latter and thus assuming that there was a common background shared with the readers. This gap gains meaning when read in its international and historical context. The 1939 First Pan-American Congress of Low-Cost Housing had served to cristallyse ideas that had been under discussion for some time before - slum clearance amongst them. Indeed, a few months after the publication of the PE, the conclusions of the Bogotá meeting were to recast some of these notions, combining state action with the idea of eradication: '[t]o recommend to the governments of the American

\footnotetext{
${ }^{38}$ James, Resistance and Integration; Massidda, "Utopian Visions....".

${ }^{39}$ Babini, Realidad y destino de la vivienda, 35.
} 
States that, in their activity programs specifically dealing with housing, they take into consideration $[. .].[\mathrm{s}]$ lum clearance (urban and rural), adopting in addition the necessary prevent slum appearance and growth'. ${ }^{40}$ Second, for what regards the incentives to the construction industry and the promotion of private initiatives for housing development, it is possible to interpret the PE as a very close reading of the Ad Hoc Committee report. The coincidences in the approach, in fact, are evident: the analysis of the housing situation, the claim that encouraging the private sector would lead to a substantive solution for the housing deficit, and even the vocabulary chosen present striking similarities.

Furthermore, both lines of thought in the PE vividly reflect the contemporary perspective of modernisation theory - a dominant mindset during the 1950s and 1960s. While a thorough analysis of such framework falls outside the scope of the present article, it is worth noting that, in line with modernization ideas, the CNV read the shantytowns as a pre-modern form of inhabitation related to a rural lifestyle which would disappear through the development of industrial forces and the expansion of urban culture. This is evident in the idea of re-educating the shantytown inhabitants to 'adapt' them to an urban lifestyle, in the hope placed on standardisation and prefabrication as solutions for the housing deficit, or in the references to the residents' 'low cultural level'. ${ }^{41}$ The modernisation perspective is also implicit in the discussions held by the IA-EcoSoc Ad Hoc Committee and in its expectations and initiatives. ${ }^{42}$

\footnotetext{
${ }^{40}$ Inter-American Economic and Social Council, First Inter-American ..., 20-21.

${ }^{41}$ Comisión Nacional de la Vivienda, Plan de Emergencia, 43 and throughout.

${ }^{42}$ Taffet, Foreign Aid as Foreign Policy, 20-23; Gorelik, "Pan American Routes"; Benmergui, "The Transnationalization...".
} 


\section{Direct Action: Eradication and 'Adaptation'}

The PE started by a description of Argentine shantytowns which stressed the precariousness of the constructions, the insufficiency of the services and the illegal status of the occupation of the plots (Fig.s 4-7). It included a census reporting a total of 112,350 people living in the villas, of which 99 per cent were in employment and 49 per cent lived at less than two kilometers from their workplaces. According to the PE, the emergence of the shantytowns had followed the migrations generated by industrialisation and had been aggravated by demagogery. Thus, the 'low cultural level' of the internal migrants led them to seek the advantages of urban life without striving to improve their habitat - an approach that was in line with usual anti-Peronist discourse. In this way the PE explanation combined ideas that were internationally accepted with its own conceptions, influenced by the local Argentine context:

Coming from poor areas, without resources and without working habits, [shantytown residents] have been attracted to the big city in search of economic betterments and the indulgences of urban life. But the social environment of the Villas Miseria, in which they have gathered by force of circumstance and for the lack of both incentives of their own and social help, contributes to worsening their natural tendencies and transforming these slums into permanent foci of epidemics and moral degradation: in their majority, their inhabitants require an urgent action of social readaptation. ${ }^{43}$

The vocabulary used to describe the shantytowns residents offers a crude glance of the way in which the PE conceived of the problem. After insisting on the 'moral misery' of the residents, 25 per cent of whom were expected to be 'individuals who could damage the social group - sick and disabled people, maladjusted and delinquent', the document stated that residents 'suffer in diverse degrees of the same social disease', have 'fallen

\footnotetext{
${ }^{43}$ Comisión Nacional de la Vivienda, Plan de Emergencia, 39.
} 
into an abyss', and wasted their scarce income on games of luck and alcohol, living in promiscuous situations and lacking any interest in saving to invest in accommodation. ${ }^{44}$ Thus, the neutral terms 'families' and 'economically weakest sectors' employed by the decree which created the CNV gradually transforms, throughout the PE, into 'intruders', 'aberrant groups of uprooted population', 'helots' and finally 'troglodytes'. ${ }^{45}$ This terminology is in line with the government's rhetoric at the time, which used to refer to the Peronist masses as groups of animals with phrases like 'aluvión zoológico' (zoological barrage) or 'las patas en la fuente' (the paws in the fountain). It is surprising to see that the CNV assessment of shantytown residents, which repeatedly labels them as indolent and careless about their living environments, is at odds with its own census and its introductory report.

The PE proposed to demolish the shantytowns and relocate their residents into purpose-built social housing conceptualized as neighbourhood units. With this the CNV implicitly picked up on Clarence Perry's notion of neighbourhood unit, relatively selfcontained and calculated and designed around the walking distance to a primary school, but added some specific further aspects. Perry's conception, celebrated by planners in the United States and the United Kingdom in the 1930s and 1940s, had in fact been mentioned by the IA-EcoSoc Ad Hoc Committee, and also discussed by Pastor in Nuestra Arquitectura. ${ }^{46}$ The PE neighbourhoods would have a community centre each (for cultural, social and sports activities); a primary school, a nursery, a centre for basic supplies; a chapel and a police station. All these uses were to be at a walking distance

\footnotetext{
${ }^{44}$ Comisión Nacional de la Vivienda, Plan de Emergencia, 14-15, 52, 43, 83 and 86 respectively.

${ }^{45}$ Comisión Nacional de la Vivienda, Plan de Emergencia, 39, 86, 86 and 219 respectively.

46 Inter-American Economic and Social Council, Problems of Housing..., 92; Perry, Neighbourhood and Community Planning; Pastor, "Anatomía de la unidad vecinal".
} 
from any point of the complex, which the Plan estimated would be about twenty hectares in size. Thus, seventeen neighbourhoods were needed, hosting 1,000 families each and leading to a density of about 300 inhabitants per hectare. The PE proposed to sell the houses to their inhabitants in instalments no higher than twenty percent of the family's income, payable over twenty years and exempt of interest. The funding source remained the state. ${ }^{47}$ Eventually only six neighbourhoods were built for this programme (Fig. 8). The final design and construction were executed by the Banco Hipotecario Nacional (National Mortgage Bank, BHN). ${ }^{48}$

The design consisted of the repetition of three housing typologies, forming rows, until the neighbourhood reached the required scale (Fig. 9). Given the CNV conception of shantytown residents, it follows that the new complexes were conceived as a means to conform them into what it considered to be the only acceptable norms. The housing unit was envisioned as an 'adaptation dwelling' where fixed steel and concrete furniture would coerce the residents into a specific lifestyle: '[i]t will be a true educational tool. It will propose a clear and comprehensible order in all the domestic tasks and will allow a direct and constant experience in the use of certain basic elements. ${ }^{49}$ The fixed furniture was meant to impose the nuclear family as household unit. ${ }^{50}$ In fact, despite the wide range of households that its own census had found, the PE only offered houses for mother, father and between three and eight children. Thus, the usual practice of hosting relatives or friends just arrived from the provinces would be hampered by this layout, while the

\footnotetext{
${ }^{47}$ Comisión Nacional de la Vivienda, Plan de Emergencia, 127-28.

${ }^{48}$ Banco Hipotecario Nacional, "Plan de Emergencia", 19-21.

${ }^{49}$ Comisión Nacional de la Vivienda, Plan de emergencia ..., 153.

${ }^{50}$ Comisión Nacional de la Vivienda, Plan de emergencia, 57; Banco Hipotecario Nacional, "Plan de Emergencia", 05.
} 
single-parent or smaller families would not really fit. In addition, the units were designed to avoid elements that the users could destroy, such as timber joinery, hinges or removable accessories, since the CNV considered these 'comforts that [the residents] are not yet in a condition to assimilate. ${ }^{51}$ Furthermore, the PE recommended allocating unfinished houses for the inhabitants to tile, plaster and paint, both to reduce costs and as part of a process of re-education through trade-training. What is not clear, though, is why, were the residents so uncivilised as the PE portrayed them, would they see the necessity of tiling and plastering their homes. In addition, as the census showed, it was not lack of insertion in the job market what kept the residents in the shantytowns, nor the need of gaining basic construction skills: 99 per cent of them were under employment, at least 10 per cent worke as builders, and most of them had self-built their shacks anyway.

The layout resulting from the repetition of units did not follow the traditional street pattern of Buenos Aires, where square blocks of roughly 100 meters each side are subdivided in 8.66 meter wide plots and occupied mainly in their perimeter, but created a new urban fabric. No reasons are given for this decision, but some hypotheses can be advanced. First, the new disposition might have been the result of the design process itself, i.e., the repetition of a given typology within the bounds of a plot in order to maximize its occupation. However, this would only explain why the design did not echo the existing fabric, but not why it failed to integrate new and old, for example through the orientation and disposition of the streets. Secondly, the somewhat North-South disposition of the strips could have been designed to facilitate even amounts of sunlight into all the houses. ${ }^{52}$ If so, however, it is unclear why they were not traced North-South

\footnotetext{
${ }^{51}$ Comisión Nacional de la Vivienda, Plan de emergencia, p.152.

52 Feinsilber, Fernandez, Salim and Vicario, "Proyecto Barrio Presidente Rivadavia", 01.
} 
exactly. As a matter of fact, the rupture in the urban fabric that the new neighbourhoods materialised can be also said to serve the civilising mission advanced by the PE. It must be remembered that the houses were considered 'adaptation dwellings', and that the neighbourhoods as a whole were thought of as machines for the re-education of their occupants. As such, they were conceived as self-contained complexes where the residents would go about their daily activities without needing to enter adjacent zones. Likewise, no institutions within the neighbourhoods were intended for residents of the surrounding area, leaving the new communities functionally isolated. To be sure, neither the CNV nor the BHN expressed the intention of purposely isolating the neighbourhoods. However, their concrete segregation stems from the design decisions made. The very idea of 'adaptation', in fact, implies that the CNV considered that shantytown residents were not ready to inhabit the city as any other citizen.

Some central tenets of modern architecture can be distinguished at the background of the PE designs: the attention to orientation, the repetition of a basic unit, and the more general design gesture of discarding the existing and creating something anew (in this case the urban fabric). The morphological simplicity of the white, flat-roof houses suits the modernist aesthetic sensitivity as well. The recourse to a low-rise housing complex can be read as a resolution to a long-standing debate in 1920s Argentina regarding social housing design: whether collective pavilions or individual houses were the ideal form. ${ }^{53}$ Through the design of rows of repetitive, modern-looking, individual housing, the BHN advanced a new step in the discussion, since it combined peculiarities of both. In this way the PE not only consolidated the role of modern architecture as the main design

\footnotetext{
${ }^{53}$ Aboy, "'The Right to a Home"”, 500-506; Ballent, Las huellas de la política.
} 
instrument preferred by the state but it also actualized it to an emerging set of debates about shantytowns and eradication.

\section{Indirect Action: Moving the Private Sector to the Fore}

In its second half the PE moved to a different range of concerns: housing costs, in particular the cost of construction, which it aimed at reducing; and private funding sources to expand the housing stock. To advise on construction costs, Section III of the PE analyzed materials, transport and labour as different agents that add to the total expenditure, dividing them by trade and supporting its claims with annexed data. As in the Ad Hoc Committee report, the $\mathrm{CNV}$ reasoning was based on the assumption that the standardisation of both materials (prefabrication) and information (statistics) would lead to a reduction in construction costs, and also help achieving the efficient building pace that the housing deficit demanded.

The economic benefits of the introduction of serial production or prefabrication were not concretely assessed by the CNV, nor was is its feasibility. On the one hand, in the context of a materials industry that clearly showed problems of infrastructure, with scarce specialized labour and high transport and energy costs, the advantages of prefabrication were not obvious, and neither was it clear who was to benefit from the implementation of this system. ${ }^{54}$ The CNV may have assumed that prefabrication meant cheaper construction and therefore cheaper housing for the whole of the population. However, this was not stated and it is not even straightforward to assume: under the existing conditions, it could not be guaranteed that prefabrication would lower costs, nor

\footnotetext{
${ }^{54}$ Lecuona, “Conceptos políticos y sociales...”, 40-44.
} 
did the CNV explain how so. In addition, even if it did, to concretely benefit the population, especially the "economically weakest sectors ${ }^{95}$ mentioned by the decree which appointed the $\mathrm{CNV}$, the promotion of prefabrication would have needed to be accompanied by other state measures protecting the end users and their access to housing, but these are absent from the PE. Thus, the ambiguity of the proposal leads to considering other possibilities. Yunovsky analyses the way in which large construction companies in Argentina lobbied for the use of specific construction systems, state subsidies and loans during 1955-1981, concluding that they participated actively in the formulation of housing policy, increasing their economic profit. ${ }^{56}$ Regarding the loans available, Yunovsky shows that the largest construction companies had connections with the lending institutions which smaller companies lacked. Extending Yunovsky's reasoning to construction materials companies, it can be seen that the use of prefabrication would have benefited only large companies, which were the ones able to work at a scale large enough to make it financially profitable. The PE, furthermore, proposed to offer lowinterest loans to construction and materials companies with more than one hundred employees, explicitly benefitting companies of concentrated capital. ${ }^{57}$

Finally, Section III of the PE highlighted three problems in relation to labour: shortage of construction workers in general, severe shortage of specialized labour, and low productivity. Standardisation, according to the PE, would help to curb the first two problems, since it would maximise the use of labour (this, of course, if accompanied by relevant training) and also systematise routines by working in plants rather than on site. In fact, years later a municipal housing commission would arrive precisely at this

\footnotetext{
${ }^{55}$ Decree 6.404.

${ }^{56}$ Yujnovsky, Claves políticas..., 11 and 43-70.

${ }^{57}$ Comisión Nacional de la Vivienda, Plan de Emergencia, 146.
} 
conclusion. ${ }^{58} \mathrm{Up}$ to this point the proposals are concise and simple. But in the paragraphs following the real dimensions of the CNV proposal begin to blur. The PE proposes to introduce labour incentives in the construction industry and yet simultaneously to reduce the impact of wages on the total cost of construction, initiatives which seem to contradict each other. Since incentives are supposed to be added to a minimum-wage, the resulting expenditure would grow instead of decrease. This ambiguity is not surprising in the political context, since the RL held an ambivalent attitude about labour at the national level. It is thus possible to suspect that, in this political context, the minimum wages would be removed and the incentives scheme used as the justification of a system in which the workers would see their financial security undermined.

The Section IV of the PE was mainly devoted to study incentives for housing investment. Housing shortage was, according to the $\mathrm{CNV}$, not only the result of insufficient construction but also a consequence of the centralisation of mortgages during Peronism and the citizens' lack of saving habits. Thus, the CNV recommended to encourage speculative housing development through tax cuts and regulation adjustments. Simultaneously it advised the national government to reduce state expenditure in direct action, thus displacing the responsibility for the population's dwelling conditions from the state to the private sector. In addition, the PE recommended to withdraw Perón's housing rental legislation, which froze rents in a context of inflation favouring tenants but discouraging investment in real estate.

The PE did not explain clearly how these strategies would help to curb the housing shortage affecting the working classes. It was not self-evident, for example, whether an expanded housing stock would automatically lead to cheaper housing since, once

\footnotetext{
${ }^{58}$ Benmergui, "Housing Development", 278.
} 
saturated the market of the middle- and upper-classes, housing investment could turn not to be profitable anymore, in which case developers may stop building. Arguably, if construction costs were to be effectively lowered by means of standardisation of materials, developers would still obtain a profit selling the units at lower prices. Still, they may prefer not to translate such margin to final prices. Furthermore, even if they did, it was not obvious whether such prices would have been at reach for those with the lowest income, since the gap between salaries and market prices was considerable. Finally, no allocation criteria were outlined, which meant that even when low-cost housing was achieved, it could have been bought by anyone, including individuals seeking either an investment opportunity or a second home, and not necessarily those in urgent need. In summary, without specific regulations neither standardisation nor expanded housing investment or lower construction costs would necessarily translate in affordable housing options for the public, but this was not a concern addressed by the CNV. The second half of the PE and its tensions with the first and with the political moment meant that it would only be implemented over time, extremely gradually and as part of later policy adjustments.

\section{Conclusions}

The direct action advised by the PE was only implemented partially, and the indirect action put into practice in some aspects, but in the longer term. ${ }^{59}$ For these reasons, it can not be simply assessed as 'successful' or 'unsuccessful', 'realised' or 'unrealised' but it should rather be read as one more link or one step (in fact, a key one) within the planning

\footnotetext{
${ }^{59}$ Benmergui, "Housing Development”, 239-252.
} 
and housing discussion in Argentina. Despite its numerous internal contradictions, the PE represented a key approach to the villas sustained by a sector of Argentine society - the one reflected by the coalition that supported the RL. This was recast, at least in some of its aspects, in 1960s and 1970s shantytown eradication initiatives. Thus, the PE can be read as an experimental first attempt of top-down eviction that would later become systematic.

During the following decades two larger shantytown eradication initiatives took place, implemented by further dictatorships: the Plan de Erradicación de Villas de Emergencia (1968) and the violent clearance carried out in the late 1970s. ${ }^{60}$ As with the $\mathrm{PE}$, these conceived of the villas as an undesirable part of the city and aimed to remove them completely, without consultation with the residents. The 1968 eradication plan, furthermore, proposed to re-accommodate evicted residents in adaptation housing as the PE had done. Furthermore, the idea of eradication persisted in legislation and in local initiatives. Amongst the latter it is worth mentioning the work of the Comisión Municipal de la Vivienda during the 1960s, which included eradication but came to be overtaken by the 1968 Plan de Erradicación de Villas de Emergencia. In terms of clearing the shantytowns, the PE did not have the results that their promoters expected. As a matter of fact, the shantytowns constituted the only feasible dwelling option for a sizeable proportion of the society and in general terms their population kept on growing until the present. Finally, this article invites further research in the field. As the first official intervention in shantytowns, the PE is surprisingly omitted from the existing urban historiography of Buenos Aires. In fact, it is possible to read it as the initial, bare

${ }^{60}$ Ministerio de Bienestar Social, Plan de Erradicación...; Snitcofsky, "Clase, territorio e historia...". 
expression of a particular Argentine approach to urban informality that soon became too politically incorrect to be enunciated crudely, but that can still be perceived today in the background of many initiatives. Since many of the urban programmes which took place during the second half of the twentieth century (in Argentina as elsewhere) are as yet unstudied, and yet they affect present affairs, the article proposes to deepen the writing of their histories. 


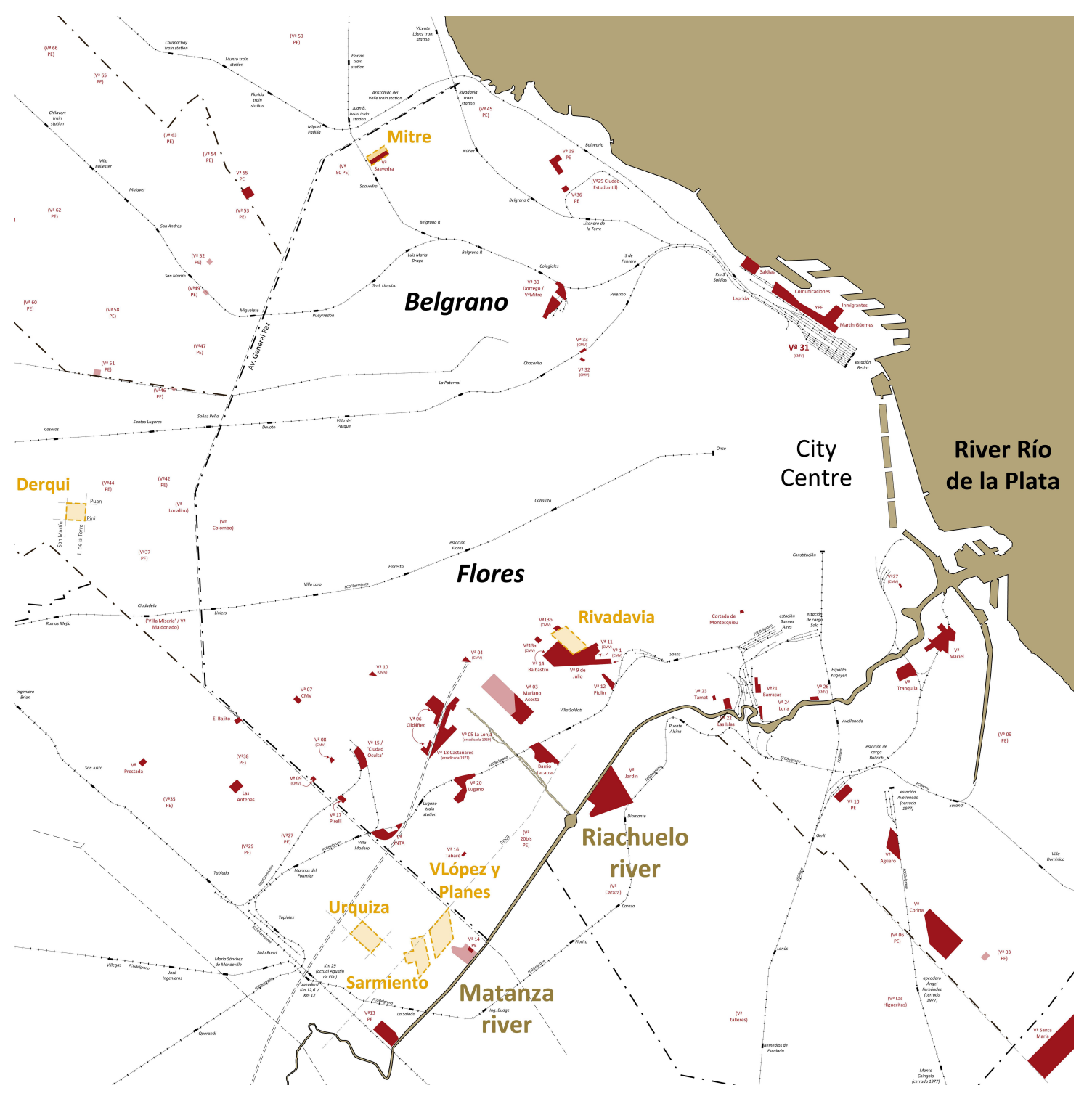

Fig. 1. Shantytowns in Buenos Aires by the mid-1950s.

The red tracing indicates the location and boundaries of the shantytowns. The yellow dotted lines indicate the neighbourhoods built as part of the Plan de Emergencia. Drawn by the author. Sources used: Comisión Nacional de la Vivienda, Plan de Emergencia, pp. 74-78; Banco Hipotecario Nacional, "Plan de Emergencia"; aerial photos provided by the Instituto Geográfico Nacional (1956) and the Mapa Interactivo of the City Government of Buenos Aires (1940 and 1965); working maps of the Comisión Municipal de la Vivienda; and the periodicals La Voz de las Villas, Nuestra Palabra, La Hora, La Prensa and La Nación amongst others. 


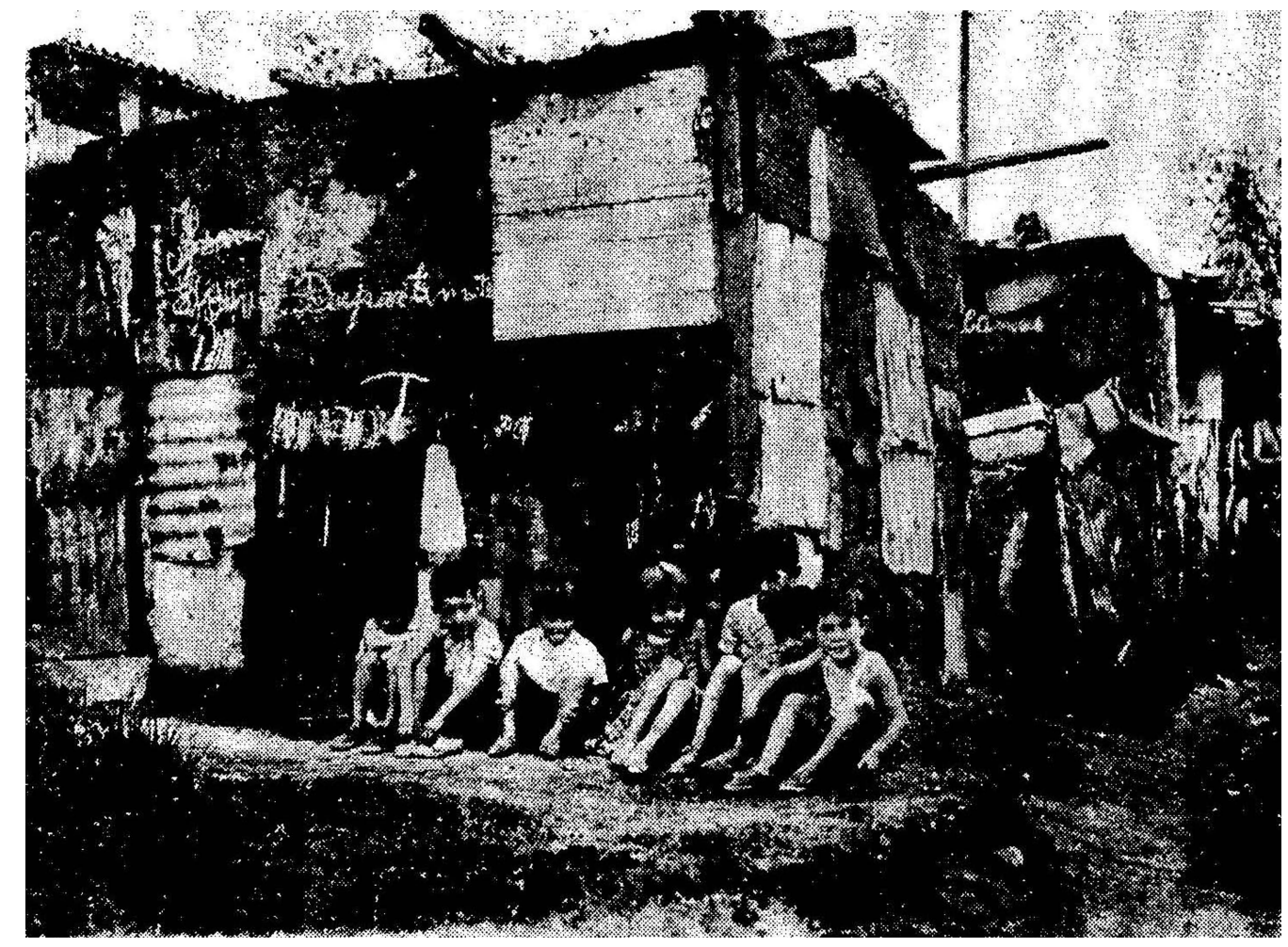

Fig. 2. Bajo Belgrano shantytown, Buenos Aires, 1955. Source: Comisión Nacional de la Vivienda, Plan de Emergencia, p. 239.

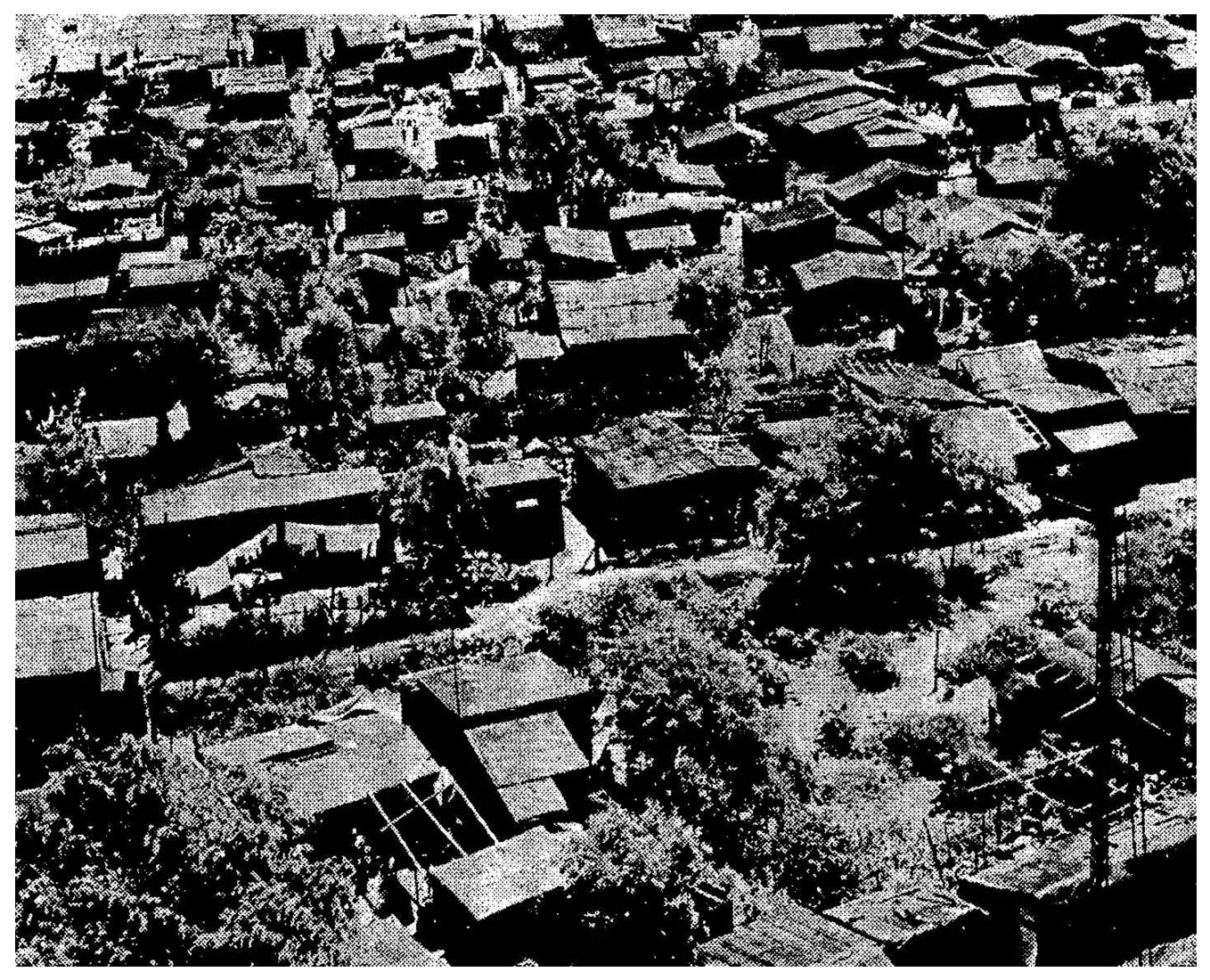

Fig. 3. Dock Sud shantytown, Buenos Aires, 1955. Source: Comisión Nacional de la Vivienda, Plan de Emergencia, p. 245. 


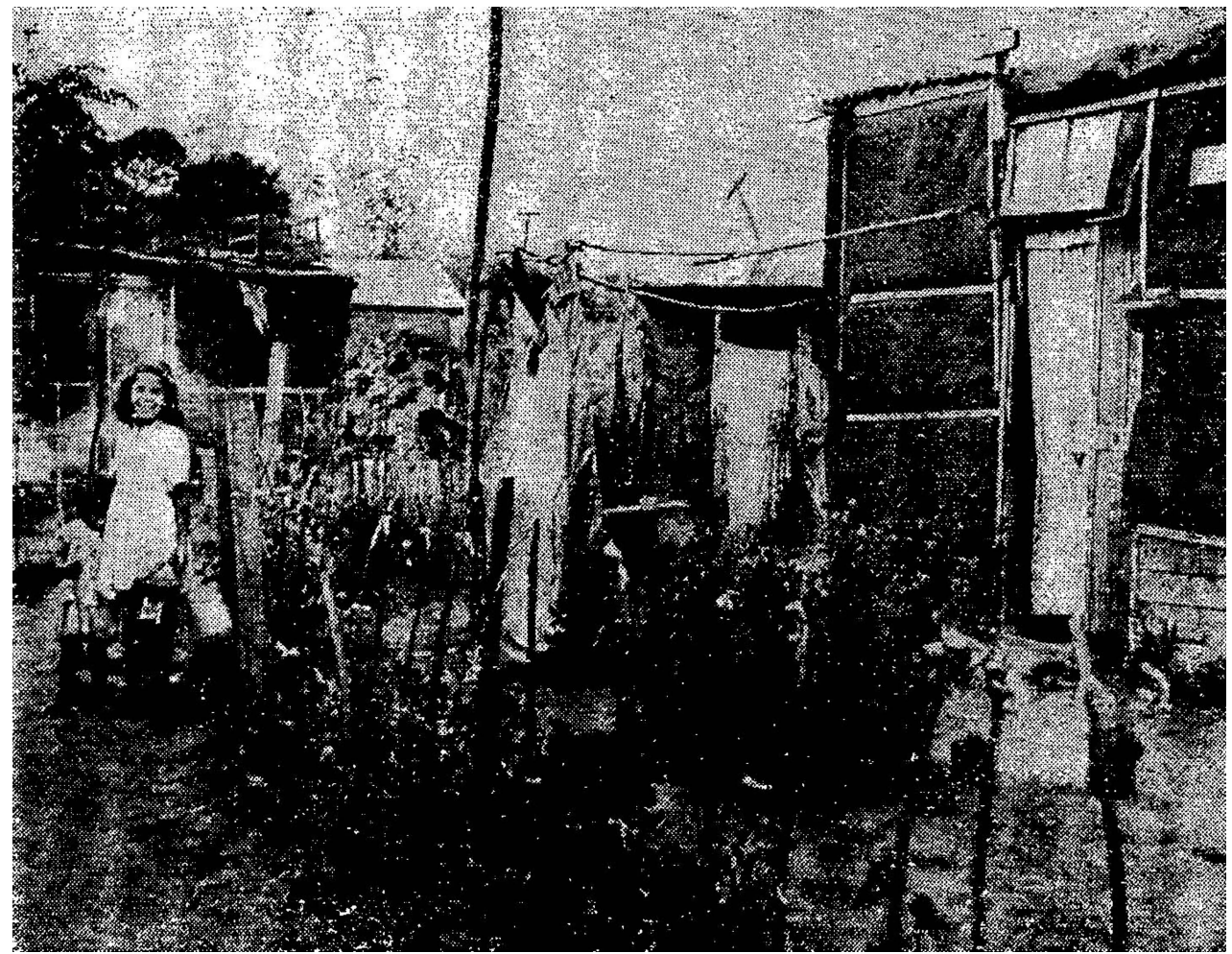

Fig. 4. Shantytown in Mataderos, Buenos Aires, 1955. Source: Comisión Nacional de la Vivienda, Plan de Emergencia, p. 242.

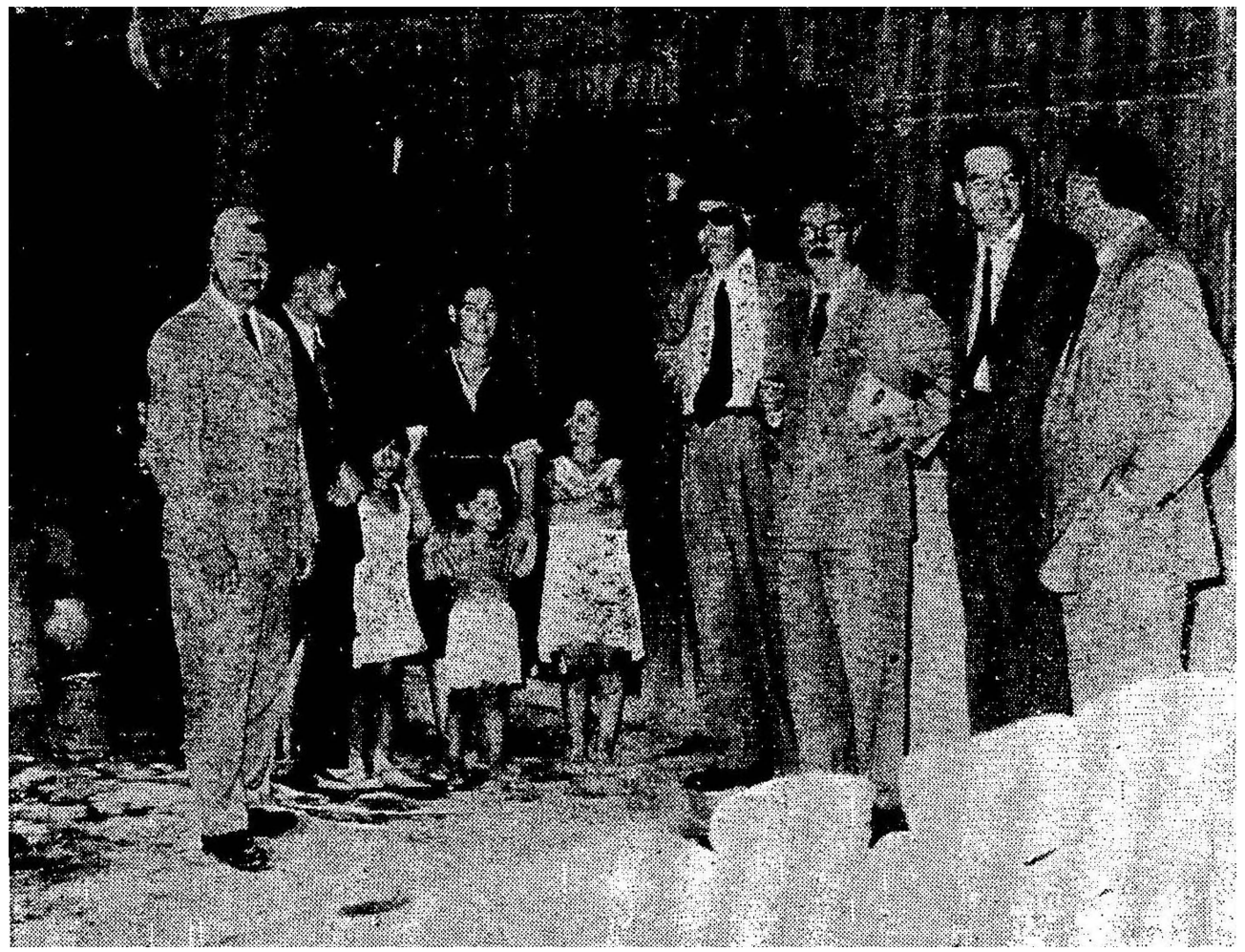

Fig. 5. Members of the Comisión Nacional de la Vivienda visiting a shantytown in the city of San Juan, capital of San Juan province, 1955. Source: Comisión Nacional de la Vivienda, Plan de Emergencia, p. 220. 


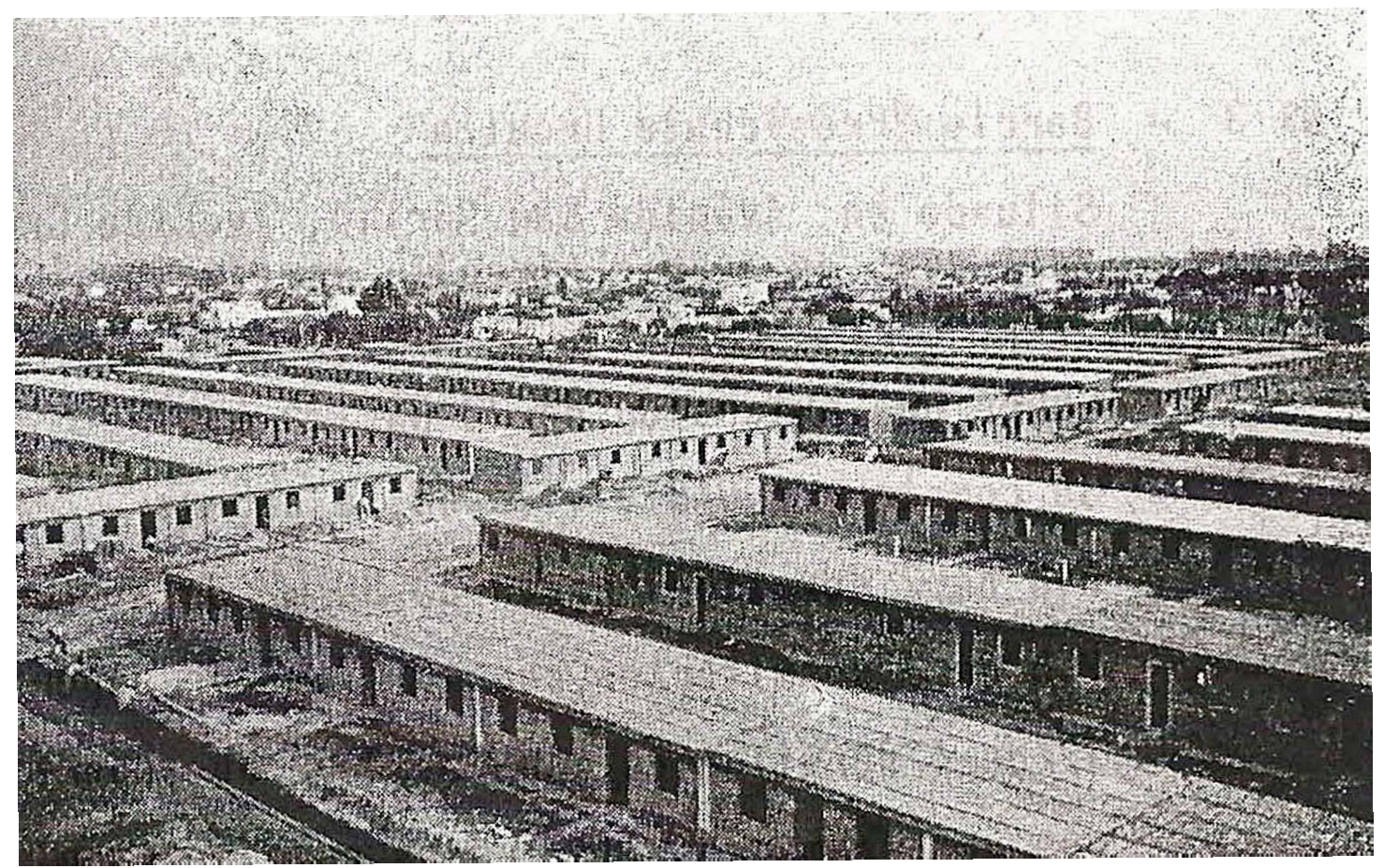

Fig. 6. Aerial view of Barrio Derqui, one of the neighbourhoods built as part of the Plan de Emergencia, shortly before its opening. Buenos Aires, Tres de Febrero district, 1958. Source: Banco Hipotecario Nacional, "Plan de Emergencia”.
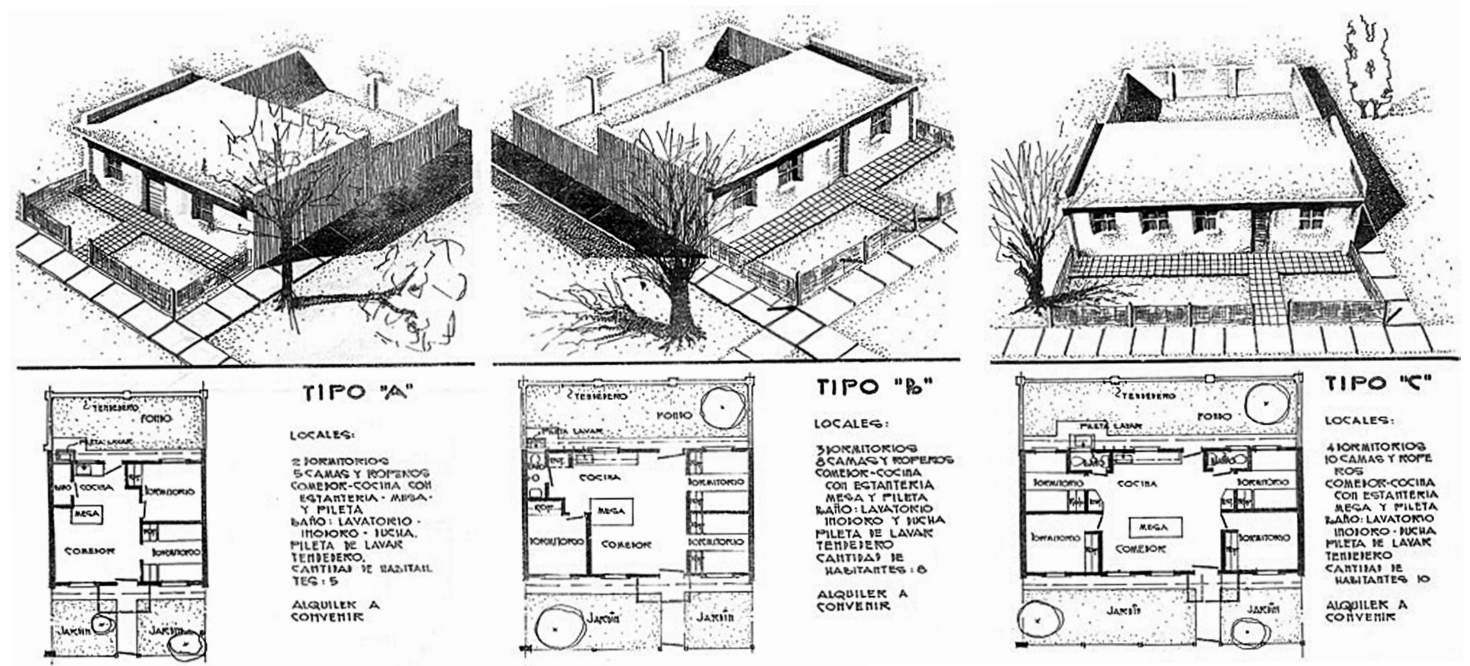

Fig. 7. Typologies used for the Plan de Emergencia. These units, organised into rows, formed the neighbourhoods built. Source: Banco Hipotecario Nacional, "Plan de Emergencia”. 